\title{
INFLUENCE OF STEAM TREATMENT AND DRYING ON CARROTS COMPOSITION AND CONCENTRATION OF PHENOLICS, ORGANIC ACIDS AND CAROTENOIDS
}

\author{
Līga Prieciṇa\# and Daina Kārkliṇa \\ Faculty of Food Technology, Latvia University of Life Sciences and Technologies, 22 Rīgas Str., Jelgava, LV-3004, LATVIA \\ \# Corresponding author, liga.priecina@Ilu.Iv
}

Contributed by Daina Kārkliṇa

\begin{abstract}
Carrot (Daucus carota $L$.) is a globally used vegetable from the Apiacea family. It contains macro and micro elements, as well as various phytochemicals. The aim of the study was to determine concentration of carotenoids and organic acids, phenolic composition and antiradical scavenging activity, and colour changes during steam-blanching (for 1.5 and $3.0 \mathrm{~min}$ ) and in dried carrots in convective and microwave-vacuum driers. Gravimetric, spectrophotometric, and high performance liquid chromatography (HPLC) methods were used for analysis. Carotenoids in fresh carrots were detected in high amounts, which decreased during thermal treatment and drying. The main organic acids in fresh carrots detected in highest amounts were oxalic, tartaric, quinic, malonic, and citric acids. Ascorbic acid concentration decreased minimally with steam processing, but significantly during drying. Fresh carrots contain minimal amounts of total phenolics, which increased during the thermal and drying processes used, while flavonoid, flavonol, flavan-3-ol and phenolic acid concentration decreased. The compound found in highest amounts by HPLC methods were 3.4-dihydroxybenzoic and 3.5-dihydroxybenzoic acids, catechin, 4-hydroxybenzoic acid, epicatechin and sinapic acid.
\end{abstract}

Key words: carrots, steaming, drying, phenolic's, organic acids.

\section{INTRODUCTION}

Carrots (Daucus carota L.) are one of the most preferred vegetables, because of their various use in culinary processes and its enriched healthy composition of phytonutrients, dietary fibre and minerals (Goncalves et al., 2010). They are noted for their rich concentration of antioxidants, especially $\beta$-carotene. They contain not only nutritional antioxidants such as vitamins $\mathrm{A}, \mathrm{C}$ and $\mathrm{E}$, but also great quantities of non-nutritional antioxidants, such as $\beta$-carotene, carotenoids, flavones, phenolic compounds etc. (Yen et al., 2008).

Blanching can be applied in food preparation using many methods including water, steam, vacuum-steam, in can and hot air. Temperature can range from $75-95{ }^{\circ} \mathrm{C}$ and time from 1-10 minutes. Blanching is commonly used as pretreatment for many techniques for example prior to freezing and drying (Rawson et al., 2011).

Convective drying, also known as hot-air drying, is the most common and widely adapted process in the food industry, requiring long drying times and high temperatures. Using this process, the colour deteriorates faster with a remarkable decrease in lightness and increase in yellowness values in many vegetables (Karam et al., 2016). Microwave drying can described as ultra-rapid energy transfer providing a quick drying method (from hours to minutes). Combining microwave energy with vacuum technology, it is possible to keep temperatures within low ranges, which is essential for heat-sensitive materials, maintaining colour, less nutrient loss, and retention of flavour (Lombrana et al., 2010).

Conventional (thermal), modern or non-thermal (e.g. high pressure processing pulsed electric field, ultrasound/ sonication, ozone, ultraviolet), domestic (e.g. washing, peeling, and cutting) and industrial (e.g. canning, drying) processing are widely reported to degrade the level of bioactive compounds in processed food products (Tiwari and Cummins, 2013). Bioactive compounds are extra-nutritional constituents that can be found in small quantities. They are easily degraded by oxygen, light, temperature and $\mathrm{pH}$. They have protective effect in diets that has been proved in many studies (Hernandez-Carrion et al., 2014). The aim of the current study was to determine concentrations of biologically active compounds (organic acids, phenolic compounds), their antiradical activity and colour changes of steam-blanched, convective, and microwave-vacuum dried carrots. 


\section{MATERIALS AND METHODS}

Chemicals. All used solvents and chemicals for extraction and analysis of carotenoids, organic acids and phenolic compounds were HPLC and analytical grade: gallic acid, 3.4-dihydroxybenzoic acid, 3.5-dihydroxybenzoic acid, (+)-catechin hydrate, chlorogenic acid, 4-hydroxybenzoic acid, vanillic acid, homovanillic acid, caffeic acid, (-)-epicatechin, syringic acid, vanillin, p-coumaric acid, sinapic acid, t-ferulic acid, 2-hydroxycinnamic acid, rutin hydrate, t(3)-hydroxycinnamic acid, quercetin, luteolin, kaempferol, acetone, methanol, ethanol, acetic acid, sodium hydroxide, aluminium chloride hexahydrate, sodium acetate anhydrous, sodium molybdate, sodium sulphate anhydrous, Folin-Ciocalteu reagent, magnesium carbonate basic, $\beta$-carotene, petroleum ether $40-60{ }^{\circ} \mathrm{C}$, hydrochloric acid, sodium nitrate, $\mathrm{m}$-phosphoric acid, oxalic acid, malic acid, malonic acid, fumaric acid, succinic acid, ascorbic acid, tartaric acid, quinic acid, benzoic acid, 2,2-diphenyl-1-picrylhydrazyl (DPPH), 2,2'-azino-bis(3-ethylbenzothiazoline-6-sulphonic acid) diammonium salt (ABTS), potassium persulphate, distilled water.

Sample preparation and drying processing. Carrots were grown and harvested in Latvia; analysis of fresh, steamblanched and dried carrots was conducted in the Faculty of Food Technology, Latvia University of Agriculture. Schematic procedure of carrot processing is shown in Figure 1.

Steam-blanching was done using a home steaming device Tefal VC4003 Vitamin+ (China) at temperature $95 \pm 3{ }^{\circ} \mathrm{C}$ temperature for 1.5 and 3.0 minutes. Carrot discs were placed in a thin layer in a steaming chamber over boiling water. After steaming samples were taken out from container and cooled to $20 \pm 2{ }^{\circ} \mathrm{C}$ (Turkmen, 2008).

Approximately $3.00 \pm 0.01 \mathrm{~kg}$ carrot discs were dried in a convective drier. Drying in a chamber type convective drier with air circulation was done in a Memmert UF55 model (Germany) with controlled speed circulation $(1.2 \pm 0.1$ $\mathrm{m} \cdot \mathrm{s}^{-1}$ ) at $45 \pm 1{ }^{\mathrm{O}} \mathrm{C}$ temperature for 12 to 14 hours. Cut samples were placed on a perforated mesh $(\varnothing 0.185 \mathrm{~m}$, bolts square $-0.030 \mathrm{~m}^{2}$ ) with holes $(\varnothing 0.002 \mathrm{~m})$; mesh occupancy $-6.70 \mathrm{~kg} \cdot \mathrm{m}^{-2}$. Samples were dried till constant non-changing moisture content (approximately from $4.00 \pm$ $0.10 \%$ till $9.00 \pm 0.10 \%)$ (Schweiggert et al., 2007)

Drying with a microwave-vacuum drier was done using an industrial Musson-1 (OOO Ingredient, Russia). The necessary amount of carrot (from $2.0-4.0 \mathrm{~kg}$ ) was prepared for drying (fresh, steamed $-1.5 \mathrm{~min}$, steamed $-3.0 \mathrm{~min}$ ) and placed in the drying cylinder (height $540 \mathrm{~mm}$, diameter 350 $\mathrm{mm}$ ), which was placed in microwave-vacuum drier (Microwave-vacuum drier Musson-1, 2007). The drying parameters were programmed pressure $-7.5 / 9.3 \mathrm{kPa}$, rotation speed of cylinder $-6 \mathrm{~min}^{-1}$, number of cycles - one. Samples were dried till moisture content $7.0-9.0 \%$ for two hours.

Two different pre-treatments were used before microwavevacuum drying: steam-blanching for 1.5 and $3.0 \mathrm{~min}$ (procedure described previously). Immediately after cooling, samples were dried in a microwave-vacuum drier as described previously. Samples were immediately analysed after the above treatments.

Moisture content. Moisture content was determined according to the AOAC standard method. Fresh samples were dried at $105 \pm 1{ }^{\circ} \mathrm{C}$ for 2 hours (Mazzeo 2011), and dried samples at $70 \pm 1{ }^{\circ} \mathrm{C}$ (Sulaiman, 2011) for 3.0 hours. Moisture content was expressed as a percentage.

Total carotenoid concentration. Total carotenoid concentration was determined according to the Russian standard ГОСТ P 54058-2010 with modifications (Anonymous, 2011). Samples were ground and milled, 1.00-2.50 g weighed into centrifuge tubes, and $0.05 \mathrm{~g}$ magnesium carbonate and $50.0 \mathrm{~mL}$ of acetone were added. Tubes were centrifuged for $15 \mathrm{~min}$ at $3500 \mathrm{rpm}$. Then the liquid was transferred to a separating funnel; the residue was centrifuged with $12.5 \mathrm{~mL}$ pure acetone 3 times $(15,10$ and $5 \mathrm{~min}$ ) and the liquid was added to a separation funnel. To purify the extract in funnel, $25.0 \mathrm{~mL}$ petroleum ether and $25.0 \mathrm{~mL}$ water were added, the solution was mixed and separated; as a result the inorganic layer was removed and the organic layer was transferred to centrifuge tubes; $1.00 \mathrm{~g}$ sodium sulphate was added to the solution. Tubes were centrifuged for $15 \mathrm{~min}$ at $3500 \mathrm{rpm}$; the obtained solution was used for spectrophotometric analysis. Absorption was read at 450 $\mathrm{nm}$ and quantification was based on the $\beta$-carotene standard curve with different concentrations $\left(0.50\right.$ to $\left.5.00 \mu \mathrm{g} \mathrm{mL}^{-1}\right)$. Obtained results were expressed as $\mathrm{mg} \beta$-carotene equivalents per 100 gram dry weight (mg $\beta$-CE $\left.100 \mathrm{~g}^{-1} \mathrm{DW}\right)$.

Extraction procedure of phenolic compounds. For phenolic compound extracts, all samples were blended or milled in equal small pieces and then $5.00 \pm 0.01 \mathrm{~g}$ for fresh and $2.50 \pm 0.01 \mathrm{~g}$ for dried mass was placed in a flask, 50.0 $\mathrm{mL}$ pure acetone was added and mechanically stirred at $18 \pm 1{ }^{\circ} \mathrm{C}$ for $1 \mathrm{~h}$. Samples were filtered and the residue was soaked in $50.0 \mathrm{~mL}$ ethanol-water (1:1) mixture and extracted for $30 \mathrm{~min}$ at $18 \pm{ }^{\circ} \mathrm{C}$. The solvent was filtered and

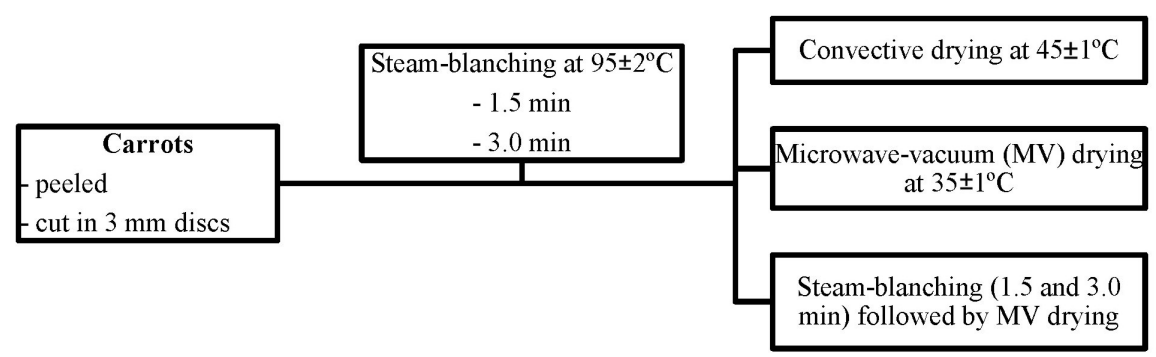

Fig. 1. Scheme of processing steps of carrots. 
the extract was stored at $4 \pm 1{ }^{\circ} \mathrm{C}$ until further analysis (max. storage time was two days). The extraction process was carried out in triplicate for each sample (Luthria, 2008; Garcia-Salas 2010).

Total phenolic compound concentration. Phenolic was determined according to the Folin-Ciocalteu method with modifications $-2.5 \mathrm{ml}$ of $0.2 \mathrm{~N}$ Folin-Ciocalteu solution in water and $2.0 \mathrm{ml} \cdot 7.5 \mathrm{~g} \cdot 100 \mathrm{ml}^{-1}$ sodium carbonate solution were added to $0.50 \mathrm{ml}$ of previously extracted samples. The resulting solution was mixed and allowed to stand for 30 $\min$ at $18 \pm 1{ }^{\circ} \mathrm{C}$. Quantification was based on a standard curve generated with $0.120 \mathrm{mg} \cdot \mathrm{ml}^{-1}$ of gallic acid. Results were expressed as milligram gallic acid equivalent per 100 gram dry weight (mg GAE.100 $\mathrm{g}^{-1} \mathrm{DW}$ ) (Pande et al. 2010).

Total flavonoid concentration. Flavinoid concentration was determined by the Olivera et al. (2008) method with modifications. To $0.50 \mathrm{ml}$ sample extract, $2.0 \mathrm{ml}$ water and $0.15 \mathrm{ml}$ sodium nitrite $\left(0.05 \mathrm{~g} \cdot \mathrm{ml}^{-1}\right)$ were added; the obtained solution was left to incubate for $5 \mathrm{~min}$. Then $0.15 \mathrm{ml}$ aluminium chloride $\left(0.10 \mathrm{~g} \cdot \mathrm{ml}^{-1}\right)$ was added and the solution incubated for $6 \mathrm{~min}$; then $1.0 \mathrm{ml} \cdot 1 \mathrm{M} \mathrm{NaOH}$ and $1.2 \mathrm{ml}$ of water were added. The solution was mixed and incubated at $18 \pm 1{ }^{\circ} \mathrm{C}$ in the dark for $20 \mathrm{~min}$. Absorbance was measured at $510 \mathrm{~nm}$. A standard curve was constructed based on a range of catechin hydrate concentrations (from 0.4 to 0.01 $\left.\mathrm{mg} \cdot \mathrm{ml}^{-1}\right)$. Results were expressed as milligram catechin equivalent per 100 gram in dry weight (mg CE $100 \mathrm{~g}^{-1}$ DW).

Total flavonol concentration. Flavonol concentration was determined by the Ložiene et al. (2007) method with slight modifications. To $2.0 \mathrm{ml}$ sample extract, $2.0 \mathrm{~mL} \mathrm{AlCl}_{3}$ solution in ethanol $\left(20 \mathrm{~g} \cdot \mathrm{l}^{-1}\right)$ and $6.0 \mathrm{ml}$ of $\mathrm{CH}_{3} \mathrm{COONa}$ solution in ethanol (50 $\left.\mathrm{g} \cdot \mathrm{l}^{-1}\right)$ were added and mixed, the obtained solution was incubated for $2.5 \mathrm{~h}$ at $18 \pm 1{ }^{\circ} \mathrm{C}$ in the dark. During incubation, the solution was mixed and was filtered just before measurement. Absorbance was measured at $440 \mathrm{~nm}$. A standard curve was constructed based on a range of rutin hydrate concentrations ( 0.2 to 0.001 $\left.\mathrm{mg} \cdot \mathrm{ml}^{-1}\right)$. Results were expressed as rutin equivalent per 100 gram in dry weight (mg RE.100 $\mathrm{g}^{-1} \mathrm{DW}$ ).

Total flavan-3-ol (proanthocyanidin) concentration. Flavan concentration was determined by the Zam (2012) method with modifications. To $1.0 \mathrm{ml}$ sample extract, 2.5 $\mathrm{mL}$ freshly prepared vanillin solution in ethanol $(1 \mathrm{~g} \cdot 100$ $\mathrm{ml}^{-1}$ ) and $2.5 \mathrm{ml} .8 \% \mathrm{HCl}$ solution in ethanol were added. The solution was mixed and incubated in a water bath at 30 $\pm 1{ }^{\circ} \mathrm{C}$ for $20 \mathrm{~min}$ and then quickly cooled to $18 \pm 1{ }^{\circ} \mathrm{C}$. Absorbance was measured at $500 \mathrm{~nm}$. A standard curve was constructed based on a range of catechin hydrate concentrations $\left(12.0\right.$ to $\left.0.1 \mathrm{mg} \cdot \mathrm{ml}^{-1}\right)$. Results were expressed as milligram catechin equivalent per 100 gram in dry weight (mg CE.100 $\left.\mathrm{g}^{-1} \mathrm{DW}\right)$.

Total phenolic acid concentration. Phenolic acid concentration was determined by the Gawlic-Dziki (2012) method with modifications. To $1.0 \mathrm{ml}$ of extract, $2.5 \mathrm{ml}$ water, $0.5 \mathrm{ml} \quad 0.5 \mathrm{M} \mathrm{HCl}, \quad 0.5 \mathrm{ml}$ Arnov reagent $(10.0 \mathrm{~g}$ $\mathrm{Na}_{2} \mathrm{MoO}_{4} * 2 \mathrm{H}_{2} \mathrm{O}$ and $10.0 \mathrm{~g} \mathrm{NaNO}_{2}$ dissolved in $100 \mathrm{ml}$ water), $0.5 \mathrm{ml} 1 \mathrm{M} \mathrm{NaOH}$ and $0.5 \mathrm{ml}$ water were added. The solution was mixed and then absorbance was measured at $490 \mathrm{~nm}$. As a blank solution, extraction solvent instead of extract was used. A standard curve was constructed based on a range of caffeic acid concentrations (0.3 to 0.001 $\left.\mathrm{mg} \cdot \mathrm{ml}^{-1}\right)$. Results were expressed as caffeic acid equivalent per 100 gram in dry weight (mg CAE.100 $\left.\mathrm{g}^{-1} \mathrm{DW}\right)$.

Determination of concentration of individual phenolic compounds. The previously mentioned extraction procedure was used. The obtained solution was distilled using a Rotatory evaporator (Heidolph Rotary Evaporator, Germany) till constant mass. Distillation temperature was $55 \pm$ $5{ }^{\circ} \mathrm{C}$ (Ti et al., 2014). The evaporated mass was dissolved in $5.0 \mathrm{ml}$ pure methanol. The methanol extract was centrifuged and filtered with a $0.45 \mu \mathrm{m}$ Millipore membrane just before analysis; pure solution was used for high performance liquid chromatography (HPLC) analysis.

Individual phenolic compounds were determined using modified the HPLC-DAD method (Shimadzu LC 20 Prominence, Japan). The method was based on chromatographic separation of phenolic compounds and their retention time. The analysis was performed at $30.0 \pm 0.1{ }^{\circ} \mathrm{C}$. The mobile phase consisted from A - distilled water; $\mathrm{B}$ - methanol; $\mathrm{C}-$ acetic acid. Injection volume was $10 \mu \mathrm{l}$. The analytic column PerkinElmer C18 $(4.6 \mathrm{~mm} \times 250 \mathrm{~mm} \times 5 \mu \mathrm{m})$ was used in the DAD SPD-M20A column. Total time of analysis was 78 min (Chen et al., 2001; Wang and Zuo, 2011; Baydar and Baydar, 2013, Lazarova et al., 2014). Parameters changed during analysis. The gradient elution was as follows: 0-2 $\mathrm{min}, 0-15 \% \mathrm{~B}, 2.5-2.4 \% \mathrm{C} ; 2-12 \mathrm{~min}$, $15-18 \%$ B, 2.4-2.2\% C; $12-20$ min, $18-20 \%$ B, 2.2-1.8\% C; 20-30 min, 20-25\% B, 1.8-1.6\% C; 30-40 min, 25-30\% B, 1.6-1.4\% C; 40-50 min, 30-45\% B, 1.4-1.0\% C; 50-55 $\min , 45-55 \% \mathrm{~B} ; 1.0-0.9 \% \mathrm{C}$; 55-65 $\mathrm{min}, 55-85 \% \mathrm{~B}$; 0.9-0.6\% C; 65-70 min, 85-100\% B, 0.6-0.0\% C; 70-73 min, $100-0 \% \mathrm{~B}, 0.0-2.5 \% \mathrm{C} ; 78 \mathrm{~min}$ stop. Flow was also changed during analysis: $0-12 \mathrm{~min}, 1.0-0.8 \mathrm{ml} \cdot \mathrm{min}^{-1}$; 12-20 $\mathrm{min}, 0.8-0.6 \mathrm{ml} \cdot \mathrm{min}^{-1}$; 20-25 $\mathrm{min}, 0.6-0.5 \mathrm{ml} \cdot \mathrm{min}^{-1}$; 25-35 $\mathrm{min}, 0.5-0.4 \mathrm{ml} \cdot \mathrm{min}^{-1} ; 35-45 \mathrm{~min}, 0.4-0.8 \mathrm{ml} \cdot \mathrm{min}^{-1}$; 45-50 $\mathrm{min}, 0.8-0.7 \mathrm{ml} \cdot \mathrm{min}^{-1} ; 50-55 \mathrm{~min}, 0.7-0.8 \mathrm{ml} \cdot \mathrm{min}^{-1}$; 55-65 $\mathrm{min}, 0.8-0.85 \mathrm{ml} \cdot \mathrm{min}^{-1}$; 65-70 $\mathrm{min}, 0.85-1.0$ $\mathrm{ml} \cdot \mathrm{min}^{-1}$.

Twenty-one standard compound mixtures were prepared at concentrations 0.05 to $1.00 \mathrm{mg} \cdot \mathrm{ml}^{-1}$ and diluted in pure methanol. Solution was stored at $4 \pm 1{ }^{\circ} \mathrm{C}$ temperature. The identification of phenolic compounds in the samples was done by comparing retention times of individual phenolic compounds in the reference vs. tested solution (qualitative analysis).

The concentration of those compounds was assessed based on comparison of peak areas obtained from the reference analysis (quantitative determination). Analysis was done in 
duplicate. Results were expressed as milligrams per 100 gram of dry weight sample (mg.100 g $\left.{ }^{-1} \mathrm{DW}\right)$.

Antiradical scavenging activity. The antiradical scavenging activity of extracts was determined on the radical scavenging ability in reaction with stable 2.2-diphenyl-1-picrylhydrazyl (DPPH) free radical according to the Afify (2012) method with modifications. Absorbance was measured at $517 \mathrm{~nm}$ using a JENWAY 630 Spectrophotometer. The antiradical activity was expressed as TROLOX (6-hydroxy2.5.7.8-tertamethylchroman-2-carboxylic acid) equivalent antiradical activity (mmoL TE.100 $\left.\mathrm{g}^{-1} \mathrm{DW}\right)$.

The antiradical scavenging activity of extracts was determined on the radical scavenging ability in reaction with ABTS $^{*+}$ radical according to the Erkan (2011) method with modifications. Absorbance was measured at $734 \mathrm{~nm}$ using a JENWAY 630 Spectrophotometer. Results were expressed as TROLOX equivalent antiradical activity (mmoL TE.100 $\mathrm{g}^{-1} \mathrm{DW}$ ) (calibration curve 10 to $1000 \mu \mathrm{moL}$ ).

Individual organic acids. Approximately $10.00 \pm 0.01 \mathrm{~g}$ fresh or $5.00 \pm 0.01 \mathrm{~g}$ dried samples were weighed in flasks and $50.0 \mathrm{ml}$ freshly prepared $\mathrm{m}$-phosphoric acid in distilled water $(\mathrm{pH}=3.00 \pm 0.20)$ was added. The samples were mixed at $18 \pm 1{ }^{\circ} \mathrm{C}$ temperature for $2 \mathrm{~h}$ and then filtered two times through Whatman filter paper and before injection in a chromatograph centrifuge and then filtered through 0.45 $\mu \mathrm{m}$ filter. A pH equal or lower than 5.00 is necessary in the mobile phase to maintain the stability of vitamin $\mathrm{C}$ during the analysis (Martin-Belloso et al., 2012; Isabelle et al., 2010).

Determination of oxalic, tartaric, quinic, malic, malonic, ascorbic, citric, fumaric, and succinic acid concentration was carried out according to Sherer et al. (2012) with modifications, using a Shimadzu LC-20 Prominence (Japan) liquid chromatograph, equipped with detector DAD SPD-M20A, auto sampler adjusted to $10 \mu \mathrm{l}$ volume injection, and Alltech $\mathrm{C} 18$ column $(5 \mu \mathrm{m}$ particle size, $250 \times 4.6$ $\mathrm{mm}$, kept at $30 \pm 0.1{ }^{\circ} \mathrm{C}$ temperature). The mobile phase consisted of acetonitrile and $0.05 \mathrm{M} \mathrm{KH}_{2} \mathrm{PO}_{4}$ (ratio 1:99) $(\mathrm{pH}=2.80 \pm 0.02$ adjusted with o-phosphoric acid) using an isocratic elution with a flow rate $1.00 \mathrm{ml} \cdot \mathrm{min}^{-1}$. Detection was done at $210 \mathrm{~nm}$. Total analysis time was up to $10 \mathrm{~min}-$ utes.

Determination of salicylic and benzoic acid concentration was carried out according to Bae et al. (2014) with modifications. It was used Shimadzu LC-20 Prominence (Japan) liquid chromatograph, equipped with detector DAD SPD-M20A, auto sampler adjusted to $10 \mu$ volume injection, Alltech C18 column $(5 \mu \mathrm{m}$ particle size, $250 \times 4.6$ $\mathrm{mm}$, kept at $25 \pm 0.1{ }^{\circ} \mathrm{C}$ ). The mobile phase consisted from acetonitrile and $0.025 \mathrm{M} \mathrm{KH}_{2} \mathrm{PO}_{4}$ (ratio $\left.45: 55\right)(\mathrm{pH}=2.55$ \pm 0.02 adjusted with o-phosphoric acid) using a gradient elution with a flow rate $1.50 \mathrm{ml} \cdot \mathrm{min}^{-1}$. Detection was at 210 $\mathrm{nm}$. Total analysis time was up till 5.5 minutes.

Colour analysis. Colour intensity of samples was measured with a Color Tec-PCM (New York, USA). Before measure- ment samples were blended in a uniform mass: fresh samples with a Braun Multiquick 5 (Poland), and dried samples with a Knifetec $^{\text {TM }} 1095$ mill (Foss, Sweden). Samples were placed in plastic petri plates in monogamous mass and then placed on the top plate. Using the equipment, a sample diameter of $80 \mathrm{~mm}$ was analysed for determination of visual colour with a computer program.

Characterising colour CIE L*a*b* space, amplitude L* represents colour intensity $\left(\mathrm{L}_{0}-\right.$ dark, $\mathrm{L}_{100}$ - light), $\mathrm{a}^{*}-$ the amount of red $(-\mathrm{a}-+\mathrm{a}), \mathrm{b}^{*}-$ yellow and blue colour amount $(-b-+b)$. Changes of colour components, compared with fresh samples (control) was characterised by the sum of the square difference - total difference $\Delta \mathrm{E}^{*}$, obtained from using $\mathrm{L}^{*} \mathrm{a} * \mathrm{~b} *$ values.

$\Delta E^{*}=\sqrt{\left(L^{*}-L_{0}^{*}\right)^{2}+\left(a^{*}-a_{0}^{*}\right)^{2}+\left(b^{*}-b_{0}^{*}\right)^{2}}$,

where: $\Delta \mathrm{E}^{*}$ - total colour difference, which characterises sample colour changes compared with a fresh sample (control); $\mathrm{L}^{*}$ - sample colour intensity characterising the value using pre-treatment; $\mathrm{L}_{0}{ }^{*}$ - sample colour intensity characterising the value in fresh samples (control); $\mathrm{a}^{*}$ - sample colour components green-red characterising values using pre-treatment; $\mathrm{a}_{0}{ }^{*}$ - sample colour components green-red characterising the value in fresh samples; $b^{*}$ - sample colour components blue-yellow characterising values using pre-treatment; $\mathrm{b}_{0}{ }^{*}$ - sample colour components blue-yellow characterising the value in fresh samples (Zhu et al., 2014; Karasu et al., 2015).

Data statistical analysis. Moisture, carotenoid, total phenolic compounds concentration were determined in triplicate, individual phenolic and organic acid compound concentration - in duplicate; colour analysis — in ten replicates. Results were calculated and presented as a mean value \pm standard deviation (SD) using Microsoft Office 2010 software. Statistically significant differences between values were calculated at the level of confidence $\alpha=0.05$ using one-way analysis of variance.

\section{RESULTS}

Moisture content of fresh carrots was $89.78 \pm 0.90 \%$ and it was minimally affected by steam-blanching. Carotenoids were the main compounds in carrots and concentration ranged from $185.17 \pm 0.55$ to $282.86 \pm 8.59 \mathrm{mg} \beta-\mathrm{CE} 100$ $\mathrm{g}^{-1}$ DW. Total phenolic compound concentration ranged from $100.37 \pm 0.84$ to $593.05 \pm 29.13 \mathrm{mg}$ GAE. $100 \mathrm{~g}^{-1}$ DW. Total phenolic acid concentration in carrots ranged from $97.50 \pm 1.54$ to $309.75 \pm 10.24 \mathrm{mg} \mathrm{CAE} \cdot 100 \mathrm{~g}^{-1} \mathrm{DW}$, and total flavonoid concentration from $135.70 \pm 4.53$ to $458.08 \pm 2.96 \mathrm{mg} \mathrm{CAE} \cdot 100 \mathrm{~g}^{-1} \mathrm{DW}$ (Table 1).

A slight increase in carotenoid concentration was observed in $1.5 \mathrm{~min}$ steam-blanched carrots, while longer steam processing resulted in a decrease. The highest increase $(67.4 \%$ higher than initial carotenoid concentration) was observed in microwave vacuum (MV) dried carrots. 
CAROTENOID AND PHENOLIC COMPOUND CONCENTRATION AND THEIR ANTIRADICAL ACTIVITY IN PROCESSED CARROTS

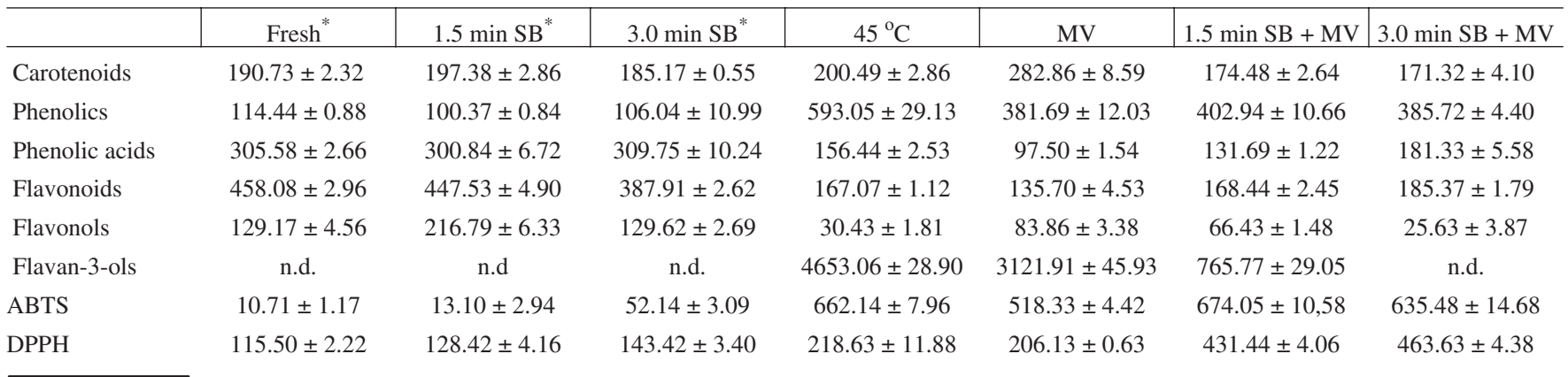

Results were expressed as average amount with standard deviation; n.d., not detected; SB, steam blanching; $45{ }^{\circ} \mathrm{C}$, convective drying; MV, microwave-vacuum drying; *Priecina and Karklina, 2014

The total phenolic concentration minimally changed with steam processing, while with convective drying content resulted in an increase by $80.7 \%$; with MV processing phenolic concentration increased by $70.0 \%$ and $71.6 \%$.

The phenolic acid concentration decreased with drying process by $48.8 \%$ with convective and by $68.1 \%$ with MV drying; steam-blanching for $1.5 \mathrm{~min}$ helped to maintain acid concentration with convective and decreased concentration by $56.9 \%$ with MV drying and with 3.0 min processing concentration decreased by $40.7 \%$. Many hypotheses have been raised to explain phenolic acid concentration changes during cooking: partial release from bounded form leading to increase in the soluble form, a decrease of the soluble fraction due to thermal degradation and an increase of the bound form caused by interactions of phenolic acids with macromolecules of the food matrix (Zaupa et al., 2015).

Flavonoids were the second major subgroup of phenolic compounds. Their concentration ranged from $135.70 \pm 4.53$ to $458.08 \pm 2.96 \mathrm{mg} \mathrm{CE} \cdot 100 \mathrm{~g}^{-1} \mathrm{DW}$. With thermal and drying, total flavonoid concentration decreased significantly. After short-term steam blanching, the concentration changed minimally, while in a longer time it decreased by $15.3 \%$; with convective drying by $63.5 \%$, and with MV processing it decreased by $70.4 \%, 63.2 \%$ and $59.5 \%$, respectively. Heat processing followed by MV drying helps to maintain flavonoid concentration more than using only the drying process.

Flavan-3-ols (proanthocyanidins) were not detected in fresh and steamed carrots, while in convective and MV dried samples they were detected in significant amounts. Using 1.5 min steam-blanching followed by MV drying, the total concentration decreased by $75.5 \%$ compared with MV dried carrots, but with 3 min pre-processing flavan-3-ols were not detected.

The antiradical activity of processed carrots is determined by two different radicals and both had a tendency to increase minimally during blanching, but significantly increased with drying.

Carrots contain a wide range of phenolic compounds, including both simple and complex phenolics. Phenolic com- pounds in the highest concentration were 3.4-dihydroxybenzoic acid, 3.5-dihydroxybenzoic acid, catechin, quercetin and luteolin (Table 2).

From the analysed 21 phenolic compounds, 11 were detected in fresh samples, 12 in steam-blanched carrots, and 18 in convective and microwave-vacuum drier processed carrots, in different concentrations depending on used method.

Organic acids in carrots were detected in various concentrations and changed differently depending on processing type. The highest concentrations of analysed organic acids were observed in dried carrots (Table 3).

Principal component analysis (PCA) shows simple visualisation of complex data according to the similarity of the grouped data. In this study, PCA was applied to access the relationships between carrot processing methods depending on the organic acid and phenolic composition. The first and second principal components ( $\mathrm{PC} 1$ and $\mathrm{PC} 2$, respectively) explained $44.24 \%$ and $22.03 \%$ of the variation (Fig. 2).

Figure 2 (a) shows clustering of the carrots in three main groups. The fresh and steam-blanched samples were separated from convective dried $\left(45{ }^{\circ} \mathrm{C}\right)$ and $\mathrm{MV}$ drier processed samples. Higher concentration of ascorbic acid, benzoic acid, 3.4-dihydroxybenzoic acid, fumaric acid, malic acid, gallic acid, rutin, quercetin and luteolin was observed in fresh and steam-blanched carrots. In convective dried carrots tartaric acid, oxalic acid, salicylic acid, citric acid, succinic acid, 4-hydroxybenzoic acid, and 2-hydroxycinnamic acid were detected in highest concentration. In MV processed carrots quinic acid, malonic acid, kaempferol, (+)-catechin, (-)-epicatechin, vanillin, 3.5-dihydroxybenzoic acid, homovanillic acid, syringic acid, t-ferulic acid, chlorogenic acid, p-coumaric acid, sinapic acid, caffeic acid, and 3-hydroxycinnmic acid had higher concentration. The PCA loading plots results depict similarity of methods based on chemical composition (Fig. 2b).

Colour is a major physical characteristics of food from a consumers' perspective. Colour in carrots during thermal and drying was analysed using the $\mathrm{L}^{*} \mathrm{a} \mathrm{b}^{*}$ spectrum and colour differences $\Delta \mathrm{E}$ (Table 4) 
PHENOLIC COMPOSITION OF PROCESSED CARROTS (mg.100 g $\left.\mathrm{g}^{-1} \mathrm{DW}\right)$

\begin{tabular}{|c|c|c|c|c|c|c|c|}
\hline & Fresh & $1.5 \mathrm{~min} \mathrm{SB}$ & $3.0 \mathrm{~min} \mathrm{SB}$ & $45{ }^{\circ} \mathrm{C}$ & MV & $\begin{array}{c}1.5 \min \mathrm{SB}+ \\
\mathrm{MV}\end{array}$ & $\begin{array}{c}3.0 \min \mathrm{SB}+ \\
\mathrm{MV}\end{array}$ \\
\hline Gallic acid & 0.294 & 1.578 & 1.934 & 0.334 & 0.413 & 0.051 & 0.029 \\
\hline 3,4-dihydroxybenzoic acid & 8.531 & 3.465 & 1.653 & 2.414 & n.d. & 1.955 & 1.726 \\
\hline 3,5-dihydroxybenzoic acid & n.d. & 0.653 & 0.511 & 1.666 & 1.068 & 1.865 & 2.286 \\
\hline (+)-catechin & n.d. & 2.086 & 1.772 & 0.819 & 1.899 & 1.044 & 4.058 \\
\hline Chlorogenic acid & n.d. & n.d. & n.d. & 0.473 & 0.860 & 0.901 & 1.741 \\
\hline 4-hydroxybenzoic acid & n.d. & n.d. & 2.828 & 7.112 & 0.433 & 1.597 & 2.355 \\
\hline Homovanillic acid & n.d. & n.d. & n.d. & 0.277 & 0.319 & 0.377 & 0.203 \\
\hline Caffeic acid & n.d. & n.d. & n.d. & n.d. & 0.386 & 0.270 & 0.380 \\
\hline (-)-epicatechin & n.d. & n.d. & n.d. & 1.729 & 2.523 & 2.123 & 2.511 \\
\hline Syringic acid & 0.085 & 0.154 & 0.162 & 0.477 & 0.398 & 0.393 & 0.364 \\
\hline Vanillin & n.d. & 0.145 & 0.128 & 0.542 & 0.547 & 0.594 & 0.664 \\
\hline Sinapic acid & 0.038 & 0.109 & 0.119 & 2.570 & 11.686 & 8.373 & 14.172 \\
\hline t-ferulic acid & 0.028 & n.d. & n.d. & 0.092 & 0.097 & 0.219 & 0.252 \\
\hline 2-hydroxycinnamic acid & 0.104 & 0.045 & 0.204 & 0.401 & 0.025 & 0.248 & 0.177 \\
\hline Rutin & 0.853 & n.d. & n.d. & 0.181 & 0.410 & 0.207 & 0.249 \\
\hline 3- hydroxycinnamic acid & 0.038 & n.d. & 0.009 & 0.185 & 3.999 & 0.313 & 0.196 \\
\hline Quercetin & 16.739 & n.d. & n.d. & n.d. & n.d. & n.d. & n.d. \\
\hline Luteolin & 2.844 & n.d. & n.d. & n.d. & n.d. & n.d. & n.d. \\
\hline Kaempferol & 0.028 & 0.009 & n.d. & n.d. & 0.041 & 0.010 & 0.082 \\
\hline Total phenolic's by HPLC & 29.583 & 8.327 & 9.507 & 19.629 & 26.407 & 20.786 & 31.699 \\
\hline
\end{tabular}

Results were expressed as average amount with $10 \%$ standard deviation; n.d., not detected; SB, steam blanching; $45^{\circ} \mathrm{C}$, convective drying; $\mathrm{MV}$, microwave vacuum drying

Table 3

ORGANIC ACIDS OF STEAM-BLANCHED AND DRIED CARROTS (mg.100 $\left.\mathrm{g}^{-1} \mathrm{DW}\right)$

\begin{tabular}{l|c|c|c|c|c|c|c}
\hline & Fresh $^{*}$ & $1.5 \mathrm{~min} \mathrm{SB}{ }^{*}$ & $3.0 \mathrm{~min} \mathrm{SB}{ }^{*}$ & $45{ }^{\circ} \mathrm{C}$ & MV & $\begin{array}{c}1.5 \operatorname{min~SB}+ \\
\text { MV }\end{array}$ & $\begin{array}{c}3.0 \mathrm{~min} \mathrm{SB}+ \\
\mathrm{MV}\end{array}$ \\
\hline Oxalic acid & 316.46 & 228.07 & 139.49 & 953.78 & 331.94 & 146.82 & 89.75 \\
Tartaric acid & 840.63 & 776.10 & 559.82 & 1553.01 & n.d. & 552.23 & 798.41 \\
Quinic acid & n.d. & n.d. & 1030.42 & n.d. & 2898.31 & 3846.49 & 935.89 \\
Malic acid & 168.19 & 301.42 & 1818.20 & n.d. & n.d. & n.d. & n.d. \\
Malonic acid & n.d. & n.d. & n.d. & 817.10 & 1281.86 & 2757.70 & 1168.83 \\
Ascorbic acid & 127.84 & 123.71 & 94.11 & 109.80 & 97.75 & 82.62 & 70.13 \\
Citric acid & 1074.49 & 321.94 & 215.79 & 4163.34 & 1378.58 & 1108.75 & 60.42 \\
Fumaric acid & 104.31 & 9.98 & 22.07 & 0.03 & n.d. & n.d. & 15.93 \\
Succinic acid & 14.57 & 79.63 & n.d. & 780.32 & 158.97 & 24.39 & 420.77 \\
Salicylic acid & n.d. & 0.60 & n.d. & 3.36 & 0.18 & 0.79 & 1.01 \\
Benzoic acid & 1.83 & 0.42 & 0.78 & 0.59 & 0.29 & 0.27 & 0.13 \\
Total org. acids & 2648.33 & 1841.87 & 3880.69 & 8381.33 & 6147.87 & 8520.07 & 3561.28
\end{tabular}

Results were expressed as average amount with $10 \%$ standard deviation; * Priecina and Karklina (2015); SB, steam blanching; $45^{\circ} \mathrm{C}$, convective drying; MV, microwave vacuum drying

With steam-blanching samples minimally changed in lightness, while $3.0 \mathrm{~min}$ steam processing produced visual changes $(\Delta \mathrm{E}>10)$. Carrots became significantly lighter with convective and MV drying, but carrots subjected to steam-blanching followed by MV drying maintained a darker colour than dried carrots without pre-processing. More visual changes were observed in dried samples without pre-processing.

\section{DISCUSSION}

Food processing (including thermal process) induces matrix disruption in lipophilic carotenoids, thereby increasing their bioavailability (Van Buggenhout et al., 2010). In plant tissues carotenoids can exist in cis and trans forms and during processing a portion of the trans form carotenoid is either lost or converted to the cis form and its derivatives, result- 

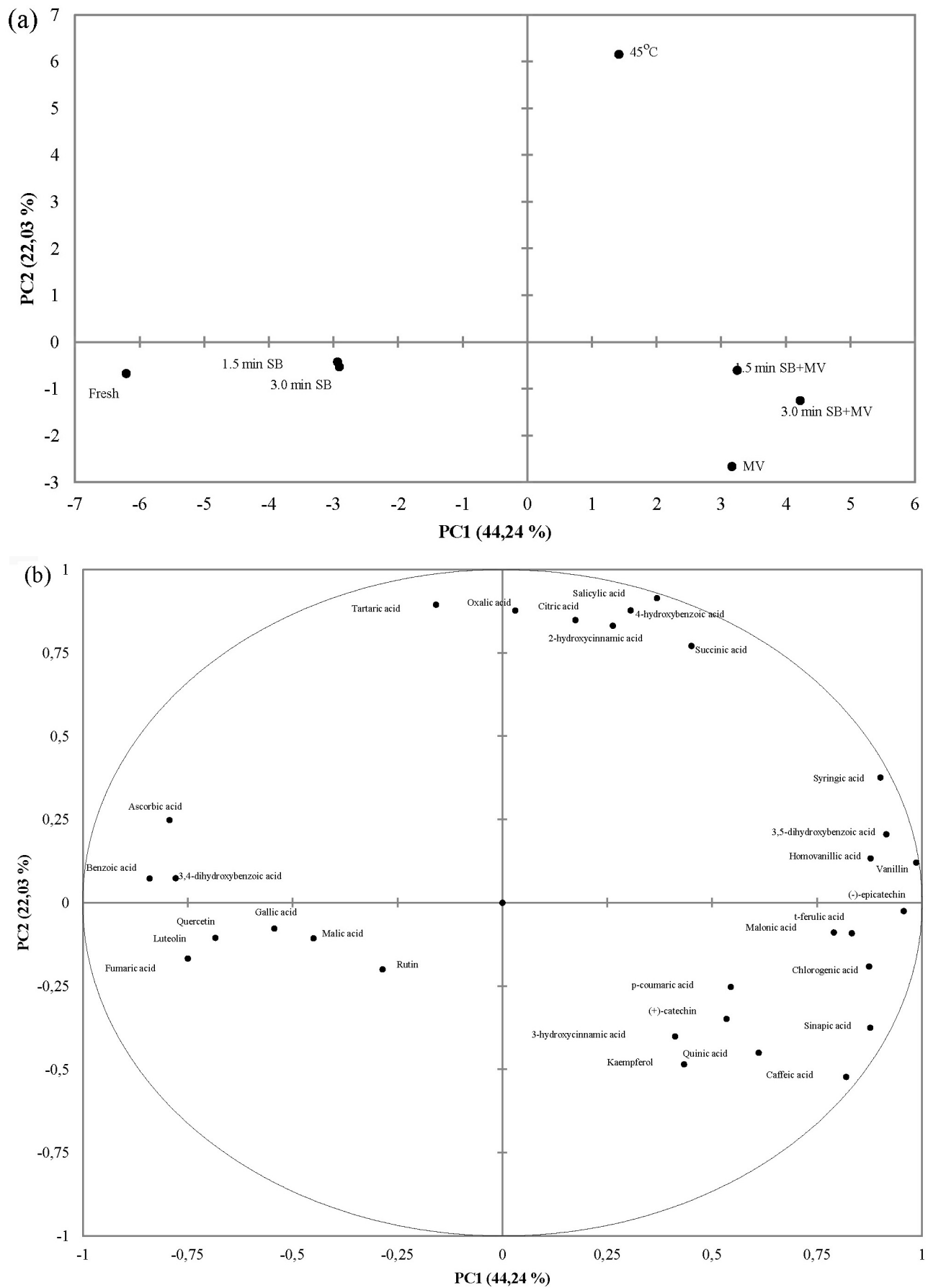

Fig. 2. (a) - scores and (b) - loading plots of principal component PC1 and PC2 of the PC analysis. Organic acid and phenolic composition data was determined after seven processing methods. SB, steam blanching; $45{ }^{\circ} \mathrm{C}$, convective drying; MV, microwave vacuum drying.

ing in increase of the total carotenoid concentration (Sharma et al., 2012). Decrease in carotenoid concentration is due to oxidation, which depends on oxygen and can be stimulated by heat and light. Also it can lead to reduction of pigment levels (carotenoids in plants are responsible for yellow and red colours of vegetables) (Murador et al., 2014).

Increase in phenolic compound concentration can occur due to thermally induced extraction of antioxidant molecules, which previously were complexed or polymerised, or retention of active compounds caused by inactivation of enzymes involved in catabolism of phenolics (Kapoor and Aggarwar,
2015). According to Guillen et al. (2017), decrease in phenolic concentration can be explained as a result of phenolic breaking down by heat, while an increase can be due to increase in the level of free flavonols caused by thermal treatment. It was suggested that anthocyanidins are unstable in nature and degradation can be caused by oxidation reactions, leading to formation of colourless phenolic aglycones (chalcone), which further transform into coumarin glycoside derivatives (Tiwari and Cummins, 2013).

Both of the used radical solutions have a specific analysis range - the ABTS radical solution estimates activity of not only phenolic compounds, but also of carotenoids, ascorbic 
Table 4

COLOUR PARAMETER CHANGES IN CARROTS USING STEAM-BLANCHING AND DRYING PROCESSES

\begin{tabular}{l|c|c|c|c}
\hline & $\mathrm{L}$ & $\mathrm{a}$ & $\mathrm{b}$ & $\Delta \mathrm{E}$ \\
\hline Fresh & $45.25 \pm 0.07$ & $17.09 \pm 0.08$ & $44.80 \pm 0.34$ & - \\
$1.5 \mathrm{~min} \mathrm{SB}$ & $48.49 \pm 0.09$ & $16.73 \pm 0.15$ & $48.63 \pm 0.39$ & $5.02 \pm 0.08$ \\
$3.0 \mathrm{~min} \mathrm{SB}$ & $48.03 \pm 0.08$ & $16.01 \pm 0.26$ & $57.12 \pm 0.60$ & $12.67 \pm 0.31$ \\
$45^{\circ} \mathrm{C}$ & $72.19 \pm 0.19$ & $17.40 \pm 0.22$ & $39.68 \pm 0.47$ & $27.42 \pm 0.23$ \\
$\mathrm{MV}$ & $72.33 \pm 0.11$ & $15.22 \pm 0.23$ & $39.19 \pm 0.30$ & $27.71 \pm 0.16$ \\
$1.5 \mathrm{~min}$ & $69.66 \pm 0.23$ & $14.71 \pm 0.35$ & $47.03 \pm 0.37$ & $24.62 \pm 0.32$ \\
$\mathrm{SB}+\mathrm{MV}$ & & & & \\
$3.0 \mathrm{~min}$ & $66.64 \pm 0.15$ & $17.15 \pm 0.28$ & $47.56 \pm 0.43$ & $21.57 \pm 0.23$ \\
$\mathrm{SB}+\mathrm{MV}$ & & & &
\end{tabular}

$\mathrm{SB}$, steam blanching; $45^{\circ} \mathrm{C}$, convective drying; MV, microwave vacuum drying

acid and other compounds as whole matrix, while the DPPH solution was specifically designed for determination of antiradical activity of phenolic compounds (Schaich et al., 2015). Besides structural characteristics (differences in hydroxylation, glycosylation, and methoxylation) of the phenolic compounds, the contents of the individual phenolics also contributes to the overall antioxidant activity (Natic et al., 2015).

Increase in 4-hydroxybenzoic acid concentration can be explained by the effect of thermal processing, which caused degradation of anthocyanin to benzoic derivatives, particularly 4-hydroxybenzoic acid. Increased temperature in combination with increased $\mathrm{pH}$ causes degradation leading to various benzoic derivatives (Patras et al., 2010). Increase of syringic acid concentration under MV conditions can be explained by accelerated thermal degradation of anthocyanin glycoside (malvidin-3-glycoside) under MV and acidic conditions (Zhao et al., 2013). As phenolic acids are susceptible to oxidation and degradation, exposure to light, oxygen and heat during food processing accelerates destruction of phenolic acids (Ravichandran et al., 2012). The obtained results showed that processing at low temperatures and using MV drying can limit the effect of oxygen and thus limit destruction of the studied phenolic acids.

3-hydroxycinnamic acid was found in low amounts that decreased with thermal processing, but increased with drying - with convective drying by $79.5 \%$ and the highest increase (by 99\%) was observed with MV drying. Rutin was detected in fresh carrots, but not after steam-blanching; with convective drying rutin concentration decreased by $78.8 \%$, while with MV processing by $51.9 \%, 75.7 \%$, and $70.8 \%$. In fresh carrots quercetin and luteolin was found in high concentration, but was not detected after thermal and drying processes.

The predominant phenolic acids in carrots are chlorogenic acid, caffeic acid, p-hydroxybenzoic acid, ferulic acid and other cinnamic acid isomers (Shahidi and Ambigaipalan, 2015). In our study chlorogenic acid had the highest concentration among phenolic acids.
Decrease in concentration of rutin, quercetin and kaempferol during thermal and drying processing can be explained by oxidation. Quercetin is unstable and is easily degraded in a slightly alkaline environment, while photodegradation has no significant effect (Dall'Acqua et al., 2012).

The main organic acid with antioxidant properties is ascorbic acid. In carrot it was found in high amounts; short term steam processes minimally affected its concentration, while longer steaming decreased concentration to $73.6 \%$ of the initial content. After convective drying carrots maintained $85.9 \%$ of the ascorbic acid concentration, while after MV drying the concentration was $76.5 \%, 64.6 \%$, and $54.9 \%$ of initial amount. Degradation of bioactive compounds (ascorbic acid and anthocyanin) can be explained by oxidation during thermal processing and drying (Rawson et al., 2011).

Principal component analysis (PCA) was used to explain differences in chemical composition between processing methods (Šumec et al., 2016).

\section{CONCLUSIONS}

The importance of the presented research lies in the underlining of the bioactive compounds of steam-blanched and differently dried carrots that need to be considered to understand composition changes during processing and loss of these compounds. It was shown that carrots are a rich source of carotenoids and short-term steam-blanching and the selected drying techniques minimally changes carotenoid concentration. HPLC analysis was used to identify and quantify amounts of phenolic compounds and organic acids by comparison with standards. Flavonoids, benzoic derivatives and main organic acids with antioxidant properties had the highest concentration in fresh and thermal processed carrots; organic acids and two phenolic acids had highest concentration in convective dried carrots, while most of the identified phenolic compounds (mostly phenolic acids) were observed in high concentration in MV drier processed carrots.

\section{ACKNOWLEDGMENTS}

This research was supported by the National Research Programme "Agricultural Resources for Sustainable Production of Qualitative and Healthy Foods in Latvia AgroBioRes" (2014-2017), Project No. 4 "Sustainable Use of Local Agricultural Resources for Qualitative and Healthy Food Product Development (FOOD)”.

\section{REFERENCES}

Afify, Ael-M., El-Beltagi, H. S., Abd El-Salam, S. M., Omran, A. A. (2012). Biochemical changes in phenols, flavonoids, tannins, vitamin E, $\beta$-carotene and antioxidant activity during soaking of three white sorghum varieties. Asian Pacific J. Trop. Biomed., 2 (3), 203-209.

Anonymous (2011). Russian National standard ГОСТ P 54058-2010. Functional Food. Method for determination of carotenoids. Russia, Moscow, 2011. Available from: http://www.internet-law.ru/gosts/gost/50791/ (accessed 31.01.2016) (in Russian) 
Bae, H., Kyon, Yun S., Hae Jun, J., Koo Yoon, I., Young Nam, E., Hyun Kwon, J. (2014). Assessment of organic acid and sugar composition in apricot, plumcot, plum, and peach during fruit development. J. Appl. Bot. Food Quality, 87, 24-29.

Baydar, N. G., Baydar, H. (2013). Phenolic compounds, antiradical activity and antiradical capacity of oil-bearing rose (Rosa damascene Mill.) extracts. Industr. Crops Prod., 41, 375-380.

Chen, H., Zuo, Y., Deng, Y. (2001). Separation and determination of flavonoids and other phenolic compounds in cranberry juice by high-performance liquid chromatography. J. Chromatogr. A, 913, 387-395.

Dall'Acqua, S., Miolo, G., Innocenti, G., Caffieri, S. (2012). The photodegradation of quercetin: Relation to oxidation. Molecules, 17, 8898-8907.

Erkan, N., Cetin, H., Ayranci, E. (2011). Antioxidant activities of Sideritis congesta Davis et Huber-Morath and Sideritis araguta Boiss et Heldr: Identification of free flavonoids and cinnamic acid derivatives. Food Res. Int., 44, 297-303.

Garcia-Salas, P., Morales-Soto, A., Segura-Carretero, A., FernandezGutierrez, A. (2010). Phenolic-compound-extraction systems for fruit and vegetable samples. Molecules, 15, 8813-8826.

Gawlic-Dziki, U. (2012). Dietary spices as natural effectors of lipoxygenase, xanthine oxidase, peroxidase and antioxidant agents. LWT-Food Sci. Technol., 47, 138-146.

Goncalves, E. M., Pinheiro, J., Abreu, M., Brandao, T. R. S., Silva, C. L. M. (2010). Carrot (Daucus carota L.) peroxidase inactivation, phenolic content and physical changes kinetics due to blanching. J. Food Eng., 97, 574-581.

Hernandez-Carrion, M., Hernando, I., Quiles, A. (2014). High hydrostatic pressure treatment as an alternative to pasteurization to maintain bioactive compound content and texture in red sweet pepper. Innov. Food Sci. Emerg. Technol., 26, 76-85.

Isabelle, M., Lee B. L, Lim, M. T., Koh, W. P., Huang, D., Ong, C. N. (2010). Antioxidant activity and profiles of common vegetables in Singapore. Food Chem., 120, 993-1003.

Kapoor, S., Aggarwal, P. (2015). Drying method affects bioactive compounds and antioxidant activity of carrot. Int. J. Veget. Sci., 21 (5), 467-481.

Karam, M. C., Petit, J., Zimmer, D., Djantou, E. B., Scher, J. (2016). Effects of drying and grinding in production of fruit and vegetable powders: A review. J. Food Eng., 188, 32-49.

Karasu, S., Kilicli, M., Baslar, M., Arici, M., Sagdic, O., Karaagalci, M. (2015). Dehydration kinetics and changes of bioactive compounds of tulip and poppy petals as a natural colorant under vacuum and oven conditions. J. Food Proc. Preserv., 39, 2096-2106.

Lazarova, I., Zengin, G., Aktumsek, A., Gevrenova, R., Ceylan, R., Uysal, S. (2014). HPLC-DAD analysis of phenolic compounds and antioxidant properties of Asphodeline lutea roots from Bulgaria and Turkey. Industr. Crops Prod., 61, 438-441.

Lombrana, J. I., Rogriguez, R., Ruiz, U. (2010). Microwave-drying of sliced mushroom. Analysis of temperature control and pressure. Innov. Food Sci. Emerg. Technol., 11, 652-660.

Ložiene, K., Venskutonis, P.R., Šipailiene, A., Labokas, J. (2007). Radical scavenging and antibacterial properties of the extracts from different Thymus pulegioides L. chemotypes. Food Chem., 103, 546-559.

Luthria, D. L. (2008). Influence of experimental conditions on the extraction of phenolic compounds from parsley (Petroselinum crispum) flakes using a pressurized liquid extractor. Food Chem., 107, 745-752.

Martin-Belloso, O., Odrizola-Serrano, I., Soliva-Fortuny, R. (2012). Vitamin C. In: Handbook of Analysis of Active Compounds in Functional Foods. Chapter 11. Nollet, L. M. L., Toldra, F. (eds.). CRC Press Taylor\&Francis Group, pp. 195-218.

Mazzeo, T., N'Dri, D., Chiavaro, E., Visconti, A., Fogliano, V. (2011). Effect of two cooking procedures on phytochemical compounds, total antiox- idant capacity and colour of selected frozen vegetables. Food Chem., 128 627-633.

Murador, D. C., de Cunha, D. T., de Rosso, V. V. (2012). Effects of cooking techniques on vegetable pigments: A meta-analytic approach to carotenoid and anthocyanin levels. Food Res. Int., 65, 177-183.

Natic, M. M., Dabic, D. C., Papetti, A., Fotiric Aksic, M. M., Ognjanov, V., Ljubojevic, M., Tesic, Z. Lj. (2015). Analysis and characterisation of phytochemicals in mulberry (Morus alba L.) fruits grown in Vojvodina, North Serbia. Food Chem., 171, 128-136.

Olivera, F. D., Vina, S. Z., Marani, C. M., Ferreyra, R. M., Mugridge, A., Chaves, A. R., Mascheroni, R. H. (2008). Effect of blanching on the quality of Brussels sprouts (Brassica olearacea L. gemmifera DC) after frozen storage". J. Food Eng., 84, 148-155.

Pande, G., Akoh, C. C. (2010). Organic acids, antioxidant capacity, phenolic content and lipid characterisation of Georgia-grown underutilized fruit crops. Food Chem., 120, 1067-1075.

Patras, A., Brunton, N. P., O’Donnell, C., Tiwari, B. K. (2010). Effect of thermal processing on anthocyanin stability in foods; mechanisms and kinetics of degradation. Trends in Food Sci. Technol., 21, 3-11.

Priecina, L., Karklina, D. (2014). Research of phenolics, flavonoids and carotenoids in vegetables and spices. In: Proceedings of the International Academic Conference on Engineering, Internet and Technology in Prague 2014, December 12-13, 2014. Prague, pp. 205-214.

Priecina, L., Karklina, D. (2015). Composition of major organic acids in vegetables and spices. In: CBU International Conference Proceedings 2015. Innovations in Science and Education, Prague, Czech Republic, 25-27 March 2015. Vol. 3, pp. 447-454.

Ravichandran, K., Ahmed, A. R., Knorr, D., Smetanska, I. (2012). The effect of different processing methods on phenolic acid content and antioxidant activity of red beet. Food Res. Int., 48, 16-20.

Rawson, A., Patras, A., Tiwari, B. K., Noci, F., Koutchma, T., Brunton, N. (2011). Effect of thermal and non-thermal processing technologies on the bioactive content of exotic fruits and their products: Review of recent advances. Food Res. Int., 44, 1875-1887.

Schaich, K. M., Tian, X., Xie, J. (2015). Hurdles and pitfalls in measuring antioxidant efficacy: A critical evaluation of ABTS, DPPH, and ORAC assays. J. Funct. Foods, 14, 111-125.

Scherer, R., Poloni Rybka, A. C., Ballus, C. A., Meinhart, A. D., Teixeira Filho, J., Teixeira Godoy, H. (2012). Validation of a HPLC method for simultaneous determination of main organic acids in fruits and juices. Food Chem., 135, 150-154.

Schweiggert, U., Carle, R., Schieber, A. (2007). Conventional and alternative procsses for spice production: a review. Trends Food Sci. Technol., 18, 260-268.

Shahidi, F., Ambigaipalan, P. (2015). Phenolics and polyphenolics in foods, beverages and spices: Antioxidant activity and health effects: a review. $J$. Funct. Foods, 18, 820-897.

Sharma, K. D., Karki, S., Thakur, N. S., Attri, S. (2012). Chemical composition, functional properties and processing of carrot: a review. J. Food Sci. Technol., 49 (1), 22-32.

Sulaiman, S. F., Bakar Sajak, A. A., Ooi, K. L., Supriatno, Seow, E. W. (2011). Effect of solvents in extracting polyphenols and antioxidants of selected raw vegetables. J. Food Compos. Anal., 24, 506-515.

Šumec, D., Maretic, M., Lugaric, I., Mešic, A., Salopek-Sondi, B., Duralija, B. (2016). Assessment of the differences in the physical, chemical and phytochemical properties of four strawberry cultivars using principal component analysis. Food Chem., 194, 828-834.

Ti, H., Li, Q., Zhang, R., Zhang, M., Deng, Y., Wei, Z., Chi, J. (2014). Free and bound phenolic profiles and antioxidant activity of milled fractions of different indica rice varieties cultivated in southern China. Food Chem., 159, 166-174. 
Tiwari, U., Cummins, E. (2013). Factors influencing levels of phytochemicals in selected fruit and vegetables during pre- and post-harvest food processing operations. Food Res. Int., 50, 497-506.

Turkmen, N., Sari, F., Velioglu, Y.S. (2008). The effect of cooking methods on total phenolics and antioxidant activity of selected green vegetables. Food Chem., 93, 713-718.

Van Buggenhout, S., Alminger, M., Lemmens, L., Colle, I., Knockaert, G., Moelants, K., Van Loey, A., Hendrickx, M. (2010). In vitro approaches to estimate the effect of food processing on carotenoid bioavailability need thorough understanding of process induced microstructural changes. Trends Food Sci. Technol., 21, 607-618.

Wang, C., Zuo, Y. (2011). Ultrasound-assisted hydrolysis and gas chromatography-mass spectrometric determination of phenolic compounds in cranberry products. Food Chem., 128, 562-568.

Received 12 October 2016

Accepted in the final form 2 January 2018
Yen, Y. H., Shih, C. H., Chang, C. H. (2008). Effect of adding ascorbic acid and glucose on the antioxidative properties during storage of dried carrots. Food Chem., 107, 265-272.

Zam, W., Bashour, G., Abdewahed, W., Khayata, W. (2012). Separation and purification of proanthocyanidins extracted from pomegranate's peels (Punica granatum). Int. J. Pharm. Sci. Nanotechnol., 3 (5), 1808-1813.

Zaupa, M., Calani, L., Del Rio, D., Brighenti, F., Pellegrini, N. (2015). Characterization of total antioxidant capacity and (poly)phenolic compounds of differently pigmented rice varieties and their changes during domestic cooking. Food Chem., 187, 338-347.

Zhao, M., Luo, Y., Li, Y., Liu, X., Wu, J., Liao, X., Chen, F. (2013). The identification of degradation products and degradation pathway of malvidin-3-glucoside and malvidin-3,5-diglucoside under microwave treatment. Food Chem., 141, 3260-3267.

Zhu, K. H., Dai, X., Guo, X., Peng, W., Zhou, H. M. (2014). Retarding effect of organic acids, hydrocolloids and microwave treatment on the discoloration of green tea flesh noodles. LWT-Food Sci. Technol., 55, 176-182.

\section{APSTRĀDES AR TVAIKU UN KALTĒŠANAS IETEKME UZ BURKĀNU FENOLU SASTĀVU, ORGANISKAJĀM SKĀBĒM UN KAROTINOİDU SATURU}

Burkāni (Daucus carota L.) ir pasaulē plaši izmantoti dārzeņi no Apiacea dzimtas, kas satur makro un mikro elementus, kā arī dažādus fitokīmiskos savienojumus. Pētījuma mērkis bija analizēt karotenoīdus, organiskās skābes, fenolu savienojumu sastāvu un to antiradikālo aktivitāti, kā arī krāsu izmaiņas pēc apstrādes ar tvaiku (1,5 un 3,0 min) un kaltētos burkānus, kas kaltēti konvekcijas un mikroviḷ̣nuvakuuma kaltēs. Analīzei tika izmantotas gravimetriskās, spektrofotometriskās un augstas izšķirtspējas škiidrumu hromatogrāfijas (HPLC) metodes. Karotenoīdi svaigos burkānos tika konstatēti lielā daudzumā, tomēr pēc termiskās apstrādes un kaltěšanas procesiem kopējais saturs samazinājās. Galvenās organiskās skābes, kas tika identificētas augstākās koncentrācijās svaigos un apstrādātos burkānos, bija skābeņskābe, vīnskābe, hīniskās, maloniskās un citronskābes. Pēc apstrādes ar tvaiku askorbīnskābes saturs samazinājās minimāli, bet pēc kaltēšanas procesa tā saturs ievērojami samazinājās. Svaigie burkāni satur minimālu kopējo fenola savienojumu saturu, un pēc termiskās apstrādes un visiem kaltēšanas procesiem šis saturs palielinājās, bet flavonoīdu, flavonolu, flavan-3-olu un fenolskābju saturs samazinājās. Izmantojot HPLC metodi, 3.4-dihidroksibenzoskābe un 3.5-dihidroksibenzoskābe, katehīns, 4-hidroksibenzoskābe, epikatehīns un sinapīnskābe bija augstākās koncentrācijās par citām identificētajām vielām. 